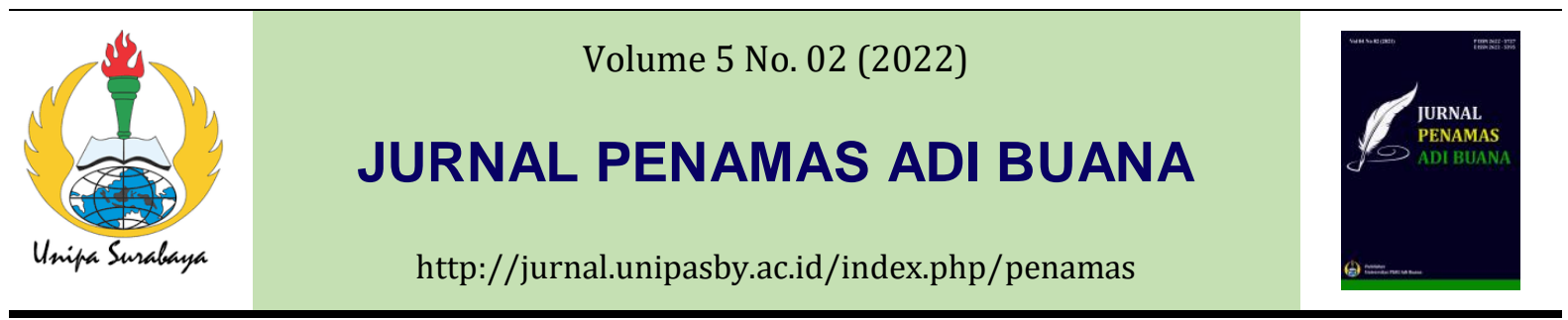

\title{
SOSIALISASI PEMANFAATAN INDUSTRI KREATIF GUNA PENINGKATAN PEREKONOMIAN MASYARAKAT DI KELURAHAN DUKUH MENANGGAL KOTA SURABAYA
}

\author{
Siti Nuurlaily Rukmana ${ }^{1 *}$, Moch.Shofwan ${ }^{1}$, Suning ${ }^{1}$, Anak Agung Sagung Alit \\ Widyastuty $^{1}$, Linda Dwi Rohmadiani ${ }^{1}$, Annisa Budhiyani $\mathbf{T}^{1}$
}

${ }^{1}$ Perencanaan Wilayah dan Kota, Universitas PGRI Adi Buana, Surabaya, Indonesia

*Email: nuurlaily_rukmana@unipasby.ac.id

\begin{abstract}
Informasi Artikel
Abstrak

Kata kunci:

Kelurahan Dukuh Menanggal memiliki penggunaan lahan yang variatif seperti sarana pendidikan, perkantoran, perdagangan dan jasa. Lahan yang variative seperti ini memicu masyarakat masyarakat membuka usaha salah satunya di sektor industri kreatif seperti kuliner, feshen, dan lainnya.

Covid-19, ekonomi, Namun masyarakat lokal tidak mengetahui bahwa usaha yang ditekuni industri kreatif termasuk pada sektor industri kreatif. Selain itu permasalahan yang terjadi yaitu terjadinya penurunan penjualan yang disebabkan pemberlakuan kebijakan Pembatasan Sosial Berskala Besar (PSBB) . Sehingga

Diterima: 13-07-2021 berdasarkan isu ini, maka dibutuhkan sosialisasi industri kreatif guna mengenalkan ke masyarakat di luar Kelurahan Dukuh Menanggal. Metode pelaksanaan yang digunakan yaitu cara sosialisasi terhadap masyarakat

Disetujui: 19-01-2022

Dipubikasikan: 31-012022 yang kemudian disebarkan kuesioner pasca sosialisasi. Hasil yang diperoleh yaitu sebelum sosialisasi $90 \%$ tidak mengetahui tentang industri kreatif dengan sebanyak $70 \%$ masyarakat yang tidak mengenal macammacam jenis kegiatan industri kreatif. Namun, pasca adanya pelatihan pengetahuan masyarakat tentang industri kreatif meningkat sebesar $90 \%$ dengan pengetahuan jenis kegiatannya adalah $70 \%$. Setelah mengetahui macam-macam jenis industri kreatif, masyarakat diminta untuk menggambarkan lokasi industri kreatif di wilayah studi yang kemudian dilanjutkan oleh pelaksana program untuk membuatkan peta pemanfaatan industri kreatif di Kelurahan Dukuh Menanggal.
\end{abstract}

\section{Abstract}

Keywords:

Dukuh Menanggal Subdistrict has diverse land uses, including educational facilities, offices, commerce, and services. Such diverse land uses to motivate people to open businesses, such as in the creative industry sector like culinary, fashion, and others. However, the local people do not aware that the business they are engaged in belongs to the creative industry sector. Furthermore, the challenge that occurred was a decrease in sales because of the implementation of the Large-Scale Social Restrictions (PSBB) policy. Therefore, based on this issue, it is necessary to socialize the creative 
industry to introduce it to the community outside Dukuh Menanggal Subdistrict. The implementation method used was socialization to the community followed by the distribution of post-socialization questionnaires. The results obtained show that before socialization, $90 \%$ of the residents did not know about the creative industry with $70 \%$ of them did not aware of the various types of creative industry activities. However, following the training, public knowledge about the creative industry increased by $90 \%$ with knowledge about the types of activities of $70 \%$. After knowing the various types of creative industries, the community was asked to describe the location of the creative industries in the study area, which was then continued by generating a map of the use of the creative industry by program implementers in the Dukuh Menanggal Subdistrict.

\section{PENDAHULUAN}

Kelurahan Dukuh Menanggal terletak di Kecamatan Gayungan Kota Surabaya, dimana berdekatan dengan kampus II Universitas PGRI Adi Buana, Surabaya (Gambar 1). Jarak antara kelurahan dengan kampus Universitas PGRI Adi Buana Surabaya (UNIPA) \pm 300 meter. Kelurahan Dukuh Menanggal Kecamatan Gayungan Kota Surabaya memiliki luas 105.967 Ha atau 10,6 Km2 dengan 31 RT dan 9 RW. Jumlah penduduk pada Tahun 2019 sebesar 8.937 jiwa dengan kepadatan penduduk 8 jiwa/ $/ \mathrm{Km}^{2}$.

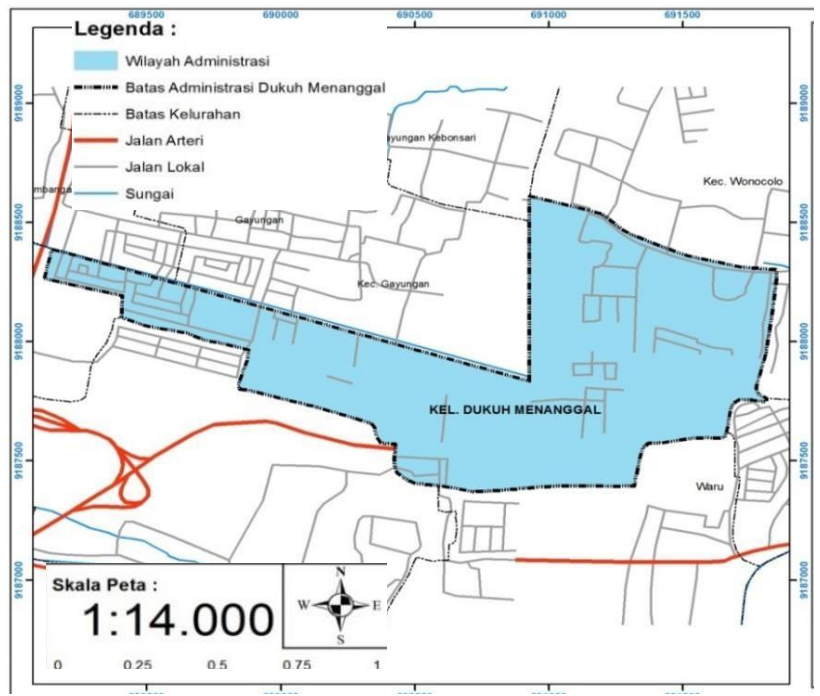

Gambar 1 Peta administrasi

Lokasi wilayah yang strategis menyebabkan penduduk datang relative besar. Jenis pekerjaan penduduk Kelurahan Dukuh Menanggal didominasi sebagai karyawan baik swasta maupun ASN. Jenis penggunaan lahan berupa pemukiman, perkantoran, perdagangan dan jasa, ruang terbuka hijau, pendidikan dan peribadatan. Masyarakat di Kelurahan Dukuh Menanggal memiliki aktifitas kegiatan yang berbeda-beda seperti bergerak dibidang kuliner (makanan), fesyen (baju-baju), bahkan sebagai tempat penginapan (seperti kos-kosan). Kegiatan masyarakat yang ada di Kelurahan Dukuh 
Menanggal ini tentu merupakan bagian support system dari kegiatan masyarakatnya. Aktivitaaktivitas ini tentu merupakan ide awal dalam mewujudkan konsep industri kreatif. Jika mengacu pada referensi (Kemendag, 2007); (Agung, 2015); (Rakib, 2017) bahwa industri kreatif merupakan industri yang memanfaatkan kreativitas, keterampilan, serta bakat individu untuk menciptakan kesejahteraan serta lapangan pekerjaan dengan memberdayakan kreasi dan daya cipta individu. Tujuan dari industri kreatif ini tentu untuk meningkatkan kesejahteraan masyarakat lokal (Fitriana, 2014); (Sopanah, Syamsul Bahri, 2020). Namun sejak pandemi Coronavirus Desease atau Covid 19 menggeparkan dunia dibeberapa bulan terakhir ini, salah satunya di Indonesia pada awal bulan Maret 2020 sampai saat ini sedang berlangsung (Februari 2021) menyebabkan terjadinya perubahan aktivitas kehidupan masyarakat, khususnya di bidang ekonomi. Terdapat beberapa dampak perubahan ekonomi akibat pandemic Covid-19, yaitu pengurangan karyawan, pengurangan jumlah pendapat pada karyawan, pemutusan hubungan kerja atau PHK (Sholikhah, Purnomo, \& Abas, 2020); (Yamali \& Putri, 2020),

Kelurahan Dukuh Menanggal yang aktivitas industri kreatif di bidang kuliner tentu akan memberikan dampak yang cukup signifikat dengan situasi pandemi Covid-19 ini. Yang awalnya kuliner ini banyak dinikmati oleh pekerja kantoran dan sivitas akademika, saat ini mengalami penurunan disebabkan adanya kebijakan Pembatasan Sosial Berskala Besar (PSBB) melalui pemberlakuan work from home (Nasution, Erlina, \& Muda, 2020); (Sahamony, Meliyani, \& Idaman, 2021). Kegiatan ini tentunya akan mengurangi pendapatan khususnya bagi yang bergerak di industri kreatif seperti kuliner/tempat makan dan feshyen. Dibutuhkan industri kreatif melalui pemetaan sub sektor yang memiliki nilai pertumbuhan yang signifikan, dan bisa diambil mulai kurun waktu 3 tahun (Agustina, Ansori, \& Pradana F.A, 2014); (Gunawan, Katili, \& Lestari, 2017). Sehingga berdasarkan isu ini, maka Langkah pertama yang dilakukan adalah sosialisasi kepada masyarakat tentang pemanfaatan peta industri kreatif dalam meningkatkan perekonomian masyarakat di Kelurahan Dukuh Menanggal, Kota Surabaya.

\section{METODE}

Metode pelaksanaan PKM ini dimulai dari perijinan dan persiapan terhadap Kelurahan Dukuh Menanggal yang kemudian dilanjutkan dengan wawancara terkait dengan isu-isu di wilayah studi. Kegiatan ini dilakukan di Kelurahan Dukuh Menanggal. Kelompok karang taruna, PKK dan aparat desa diundang untuk berkumpul di kantor desa untuk kemudian diberikan materi tentang pemanfaatan peta industri kreatif di Kelurahan Dukuh Menanggal. Pelaksanaan kegiatan PKM ini dapat dilihat pada skematik rancangan pelaksanaan pada gambar 2 


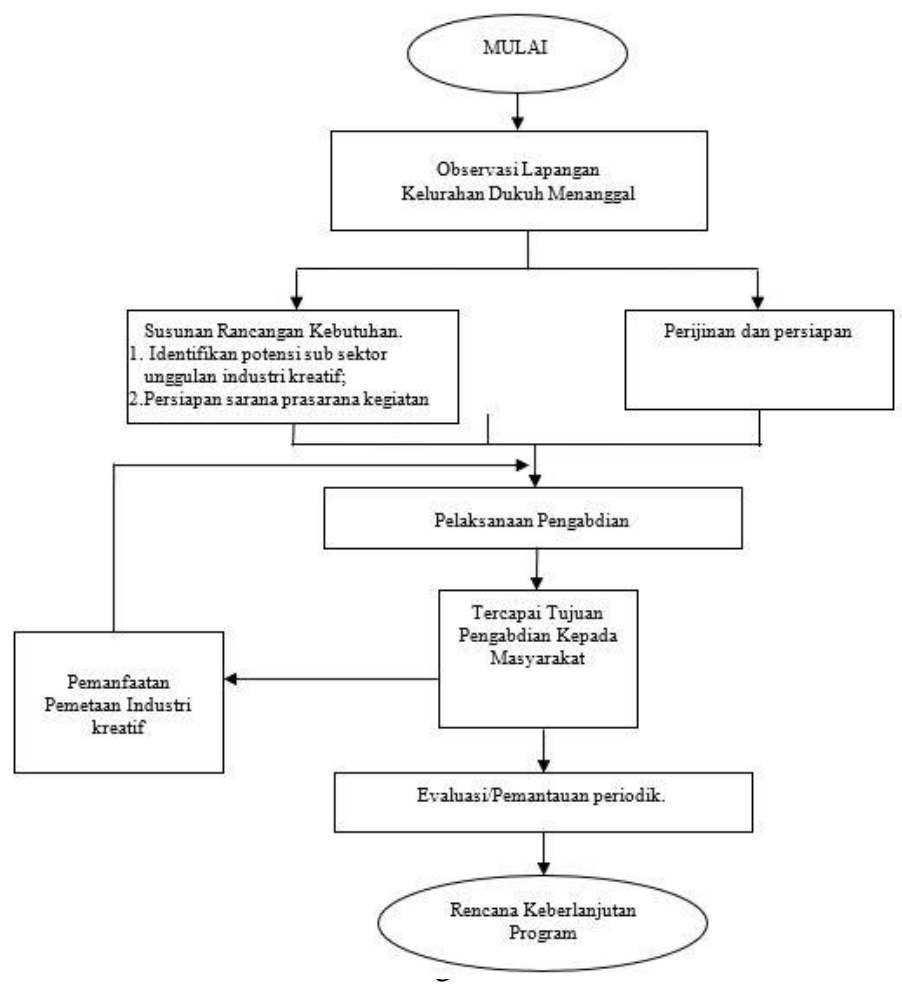

Gambar 2 Metode Pelaksanaan PKM

Berdasarkan Skema perancangan di Gambar 2 maka dapat dijelaskan Langkah-langkah yang harus dipersiapkan, yaitu:

1. Pembuatan peta industri kreatif, dimulai dari identifikasi potensi yang di klasifikasikan dari 14 sub sektor di bidang industri kreatif;

2. Kegiatan pembuatan peta meliputi: survei pendahuluan, pembelian material (ex. Triplek, cat kayu, kuas, dll)

3. Melakukan konsultasi publik bersama perwakilan dari aparatur desa, ketua RT dan perwakilan masayarakat untuk menentukan sebaran potensi industri kreatif.

4. Pengolahan data dari hasil konsultasi publik yang kemudian dilakukan analisis spasial, dimana hasilnya berupa peta sebaran industri kreatif

5. Setelah peta sebaran selesai, maka dilakukan sosialisasi terhadap masyarakat khususnya dalam pengetahuan industri kreatif. Penyebaran kuesioner berupa pre-test dan post test dilakukan guna melakukan monitoring dan evaluasi hasil kegiatan ini.

Guna tercapainya tujuan dari program kegiatan masyarakat ini, maka gambaran teknologi yang ditawarkan adalah pemetaan pemafaatan industri kreatif di Kelurahan Dukuh Menanggal. Adapun proses yang diterapkan adalah: 
1. Pembuatan peta industri kreatif $\rightarrow$ dilakukan setelah melaksanakan diskusi publik;

2. Kegiatan pembuatan peta, meliputi:
a. Survei lapangan,
b. Konsultasi dan musyawarah dengan Perangkat Desa,
c. Pembelian material seperti triplek, Cat kayu, Kuas dan lain-lain,
d. Pengecatan,
e. Pemasangan,
f. Dokumentasi

3. Kegiatan finishing:
a. Triplek untuk membuat alas
b. $\quad 1 \times 2$ bilah kayu
c. $\quad 0.5 \mathrm{~cm}$ paku semat persegi yang warnanya cocok atau justru kontras dengan warna bingkai.
d. Paku semat bulat (pasak kayu) berdiameter $5 \mathrm{~mm}$
e. Miter box (kotak potong sudut), gergaji, penggaris siku-siku, meteran gulung
f. Lem dan karet gelang
g. Proses Pengecatan. cat tidak harus cat mobil gunakan jenis yang lebih murah dengan tinner b sudah cukup sebab nantinya pun akan dilakukan proses clear

4. Pewarnaan pada logo bisa dilakukan dengan proses spon yaitu menggunakan kain yang di celup ke cat, karena biasanya logo ukurannya lebih kecil. sebelum di clear, atau setelah dicat dan pelepasan lakban biasanya akan ada goresan goresan cacat jangan panik gunakan saja trak pen.

\section{HASIL DAN PEMBAHASAN}

Hasil dari program kepada masyarakat yang dilaksanakan oleh Program Studi Perencanaan Wilayah dan Kota sebagai berikut:

\section{Identifikasi Lokasi Kegiatan}

a. Kondisi Awal

Kelurahan Dukuh Menanggal memiliki karakteristik penggunaan lahan yang cukup variatif. Penggunaan lahan yang ada dimulai dari fasilitas Pendidikan, perkantoran, perdagangan dan jasa. Hal 
ini yang mendukung berkembangnya kegiatan industri kreatif salah satunya. Namun tidak adanya papan informasi pemanfaatan industri kreatif akan mempersulit memperkenalkan kepada masyarakat di luar kelurahan khususnya terkait potensi industri kreatif.

\section{b. Kondisi Akhir}

Adanya papan informasi tidak hanya masyarakat di lingkungan Dukuh Menanggal yang mengetahui potensinya melainkan juga masyarakat pendatang. Hal ini dilakukan merupakan salah satu bentuk promosi industri kreatif di Kelurahan Dukuh Menanggal (Gambar 3)

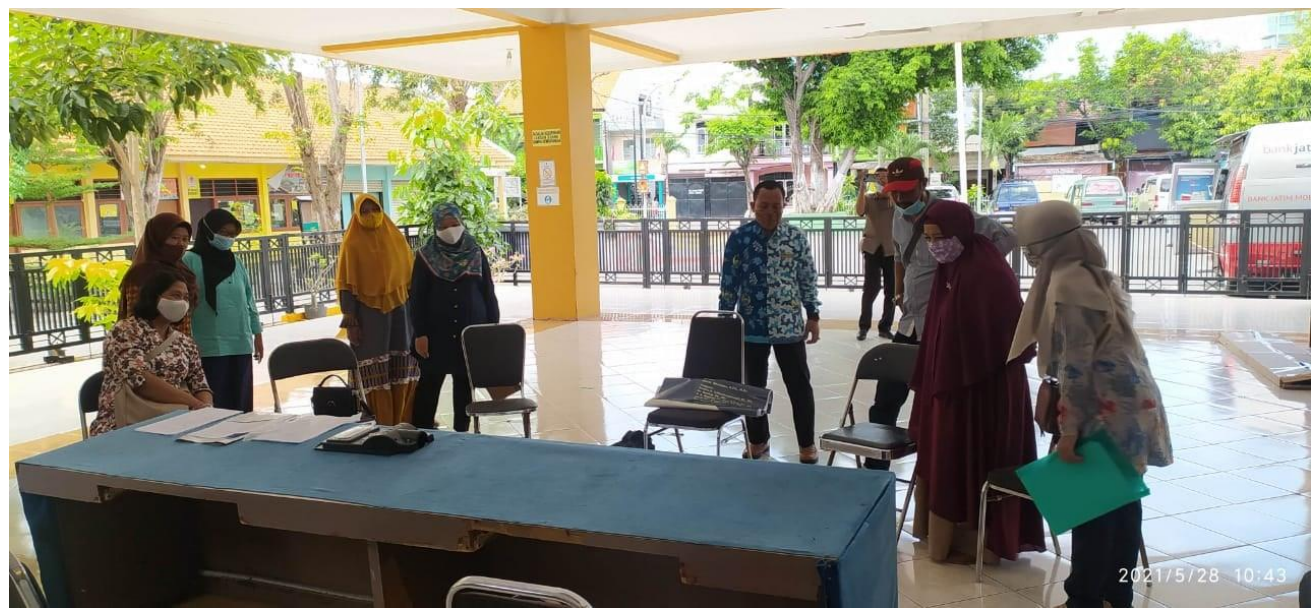

Sumber: Survei, 2021

Gambar 3 Kegiatan Penyuluhan dan Sosialisasi Pemanfaatan Peta Industri Kreatif

Guna mencapai tujuan dari pelaksanaan sosialisasi pemanfaatan industri kreatif ini, maka dibuatlah peta yang ada gambar 4. Pelaksanaan sosialisasi ini dilakukan di Kelurahan Dukuh Menanggal
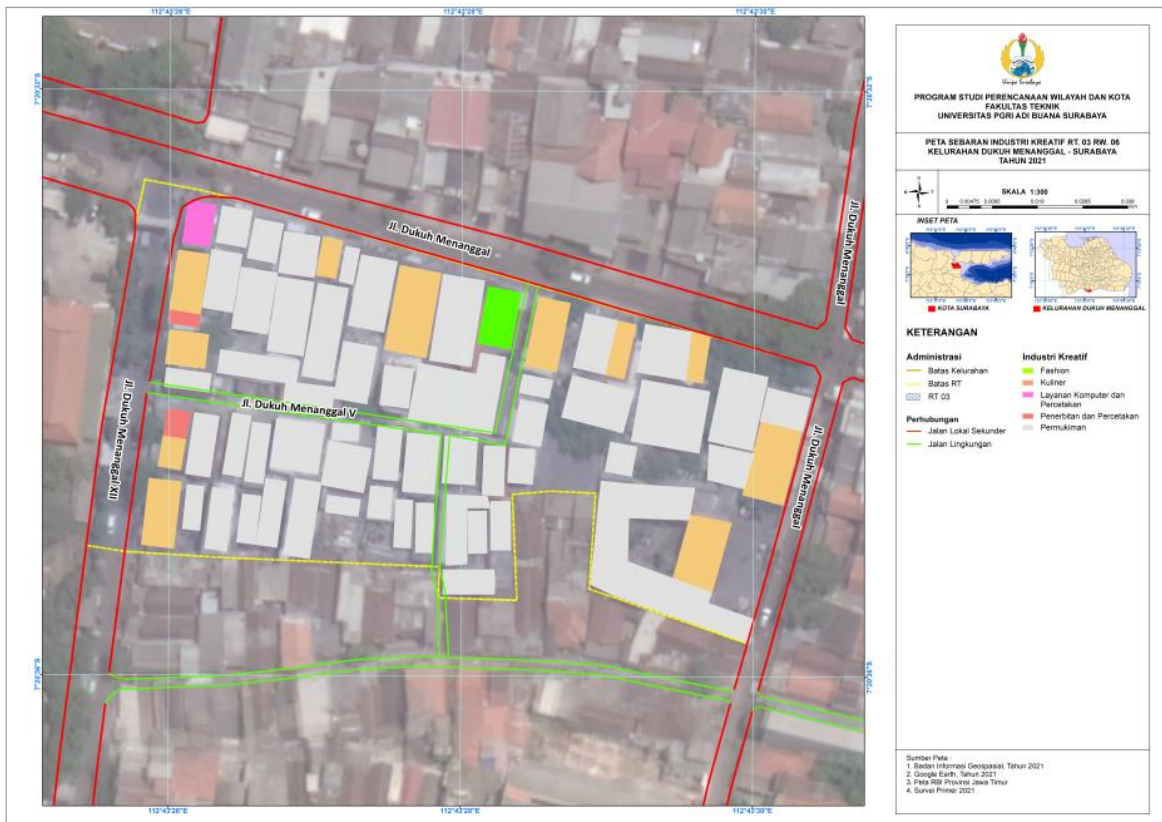


\section{Sumber: Survei 2021}

Gambar 4 Peta Sebaran Industri Kreatif

Berdasarkan gambar 4 diketahui bahwa industri kreatif yang ada di Kelurahan Dukuh Menanggal ada 5 jenis, yaitu:

1. Fashion

2. Kuliner

3. Layanan komputer dan percetakan

4. Penerbitan dan Percetakan

Kegiatan sosialisasi ini ditutup dengan penyerahan barang khususnya peta industri kreatif yang ada di kelurahan Dukuh Menanggang Kota Surabaya (Gambar 5)

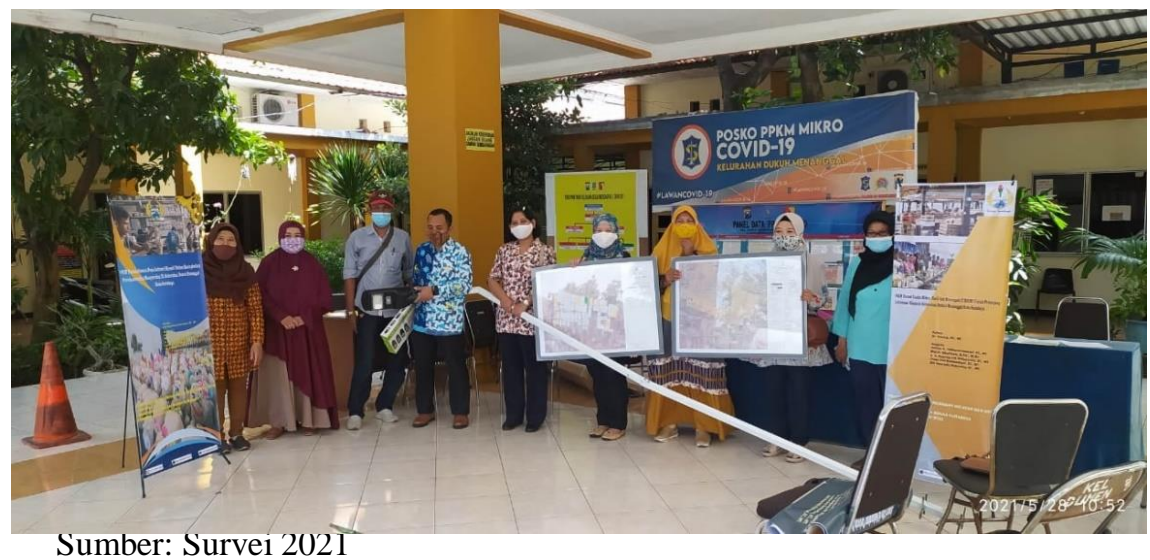

Gambar 5 Serah Terima Barang Kepada Kelurahan Dukuh Menanggal

\section{Pemahaman Tentang Pemanfaatan Industri Kreatif}

Pemahaman tentang industri kreatif ini dilakukan sebelum dan sesudah pelaksanaan sosialisasi pemanfataan indutri kreatif di Kelurahan Dukuh Menanggal. Metode yang digunakan dengan menyebarkan kuesioner kepada peserta kegiatan PKM ini. Ada pun hasil kuesioner yang diperoleh sebelum dan sesudah kegiatan diuraikan pada gambar 6-7:

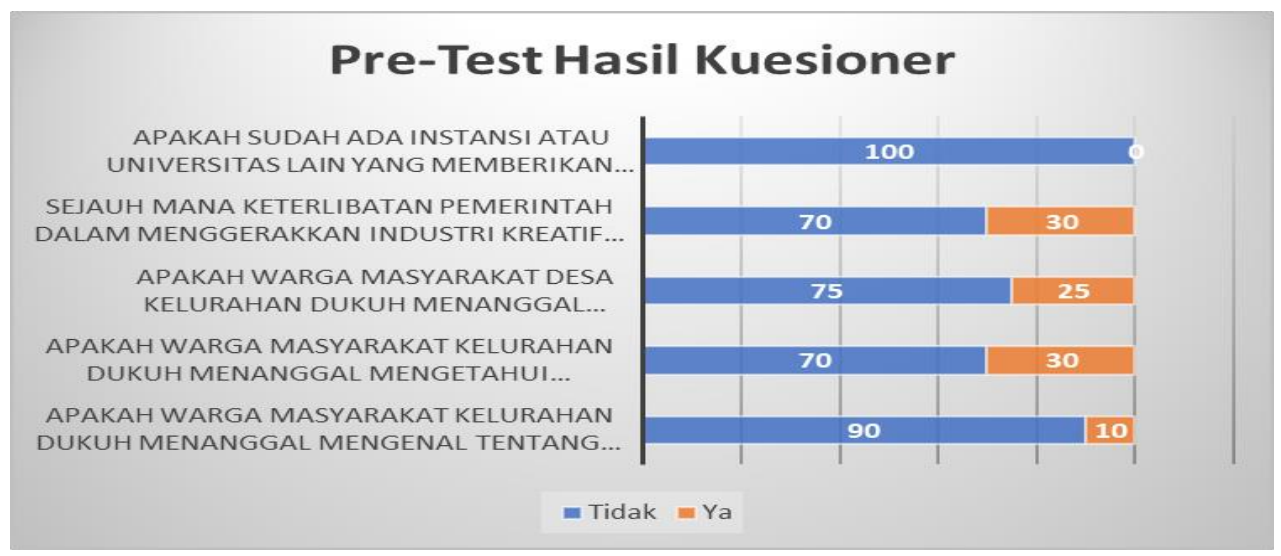

Sumber: Analisis, 2021 
Gambar 6. Presentase Pre-Test Hasil Kuesioner

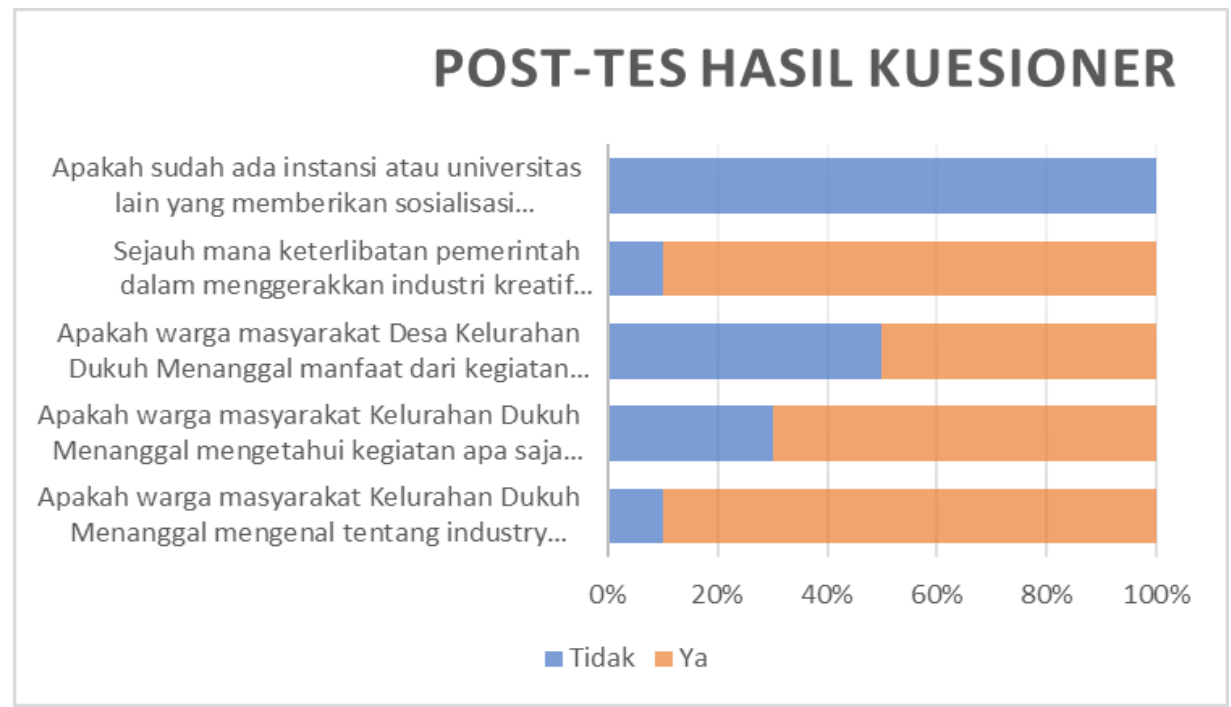

Sumber: Analisis, 2021

Gambar 7. Presentase Post-Test Hasil Kuesioner

Berdasarkan Gambar 6 - 7 diketahui bahwa sebelum adanya sosialisasi industri kreatif masyarakat di Kelurahan Dukuh Menanggal hanya mengetahui $\pm 30 \%$ terkait dengan jenis kegiatan yang termasuk dalam sektor industri kreatif dengan pengetahuan yang sangat minim sekali yaitu 90\% masyarakatnya tidak mengenal industri kreatif. Namun dengan setelah adanya sosialisasi, masyarakat telah mengetahui kegiatan apa saja yang termasuk industri kreatif sebesar 70\%. Hal ini disebebkan $90 \%$ masyarakatnya mengenal industri kreatif sebesar $90 \%$.

\section{KESIMPULAN}

Pelaksanaan pengabdian dengan judul sosialisasi pemanfaatan peta industri kreatif di Kelurahahan Dukuh Menanggal Kota Surabaya telah berjalan cukup baik. Hasil yang diperoleh dari pelaksanaan pengabdian ini yaitu 1 buah peta sebaran industri kreatif dan peningkatan pengetahuan masyarakat lokal terhadap industri kreatif di lingkungannya. Berdasarkan hasil monitoring dan evaluasi dengan metode penyebaran kuesioner, maka pengetahuan masyarakat meningkat, yang awalnya hanya $10 \%$ menjadi $90 \%$.

\section{UCAPAN TERIMAKASIH}

Terimakasih kepada seluruh aparatur kelurahan Dukuh menanggal yang terlibat serta program studi Perencanaan Wilayah dan Kota. Kegiatan pengabdian ini juga di danai oleh Universitas PGRI Adi Buana Surabay.

\section{DAFTAR PUSTAKA}

Agung, A. A. G. (2015). Berbasis Industri Kreatif Berwawasan Kearifan. Jurnal Ilmu Sosial Dan Humaniora, 4(2), 585-597. 
Agustina, F., Ansori, N., \& Pradana F.A, T. (2014). Pemetaan Industri Kreatif Dan Penentuan Kompetensi Inti Bangkalan. Jurnal Teknik Industri, 14(2), 131. https://doi.org/10.22219/jtiumm.vol14.no2.131-138

Fitriana, A. N. (2014). Pengembangan Industri Kreatif Di Kota Batu (Studi Tentang Industri Kreatif Sektor Kerajinan Di Kota Batu). Jurnal Administrasi Publik Mahasiswa Universitas Brawijaya, 2(2), 281-286.

Gunawan, A., Katili, P. B., \& Lestari, M. (2017). Pemetaan Potensi Industri Kreatif Unggulan Untuk Meningkatkan Pertumbuhan Ekonomi. Journal Industrial Servicess, 3(1), 203-209. Retrieved from http://jurnal.untirta.ac.id/index.php/jiss/article/view/2086

Nasution, D. A. D., Erlina, E., \& Muda, I. (2020). Dampak Pandemi COVID-19 terhadap Perekonomian Indonesia. Jurnal Benefita, 5(2), 212. https://doi.org/10.22216/jbe.v5i2.5313

Rakib, M. (2017). Strategi Pengembangan Ekonomi Kreatif Berbasis Kearifan Lokal Sebagai Penunjang Daya Tarik Wisata. Journal of Chemical Information and Modeling, 8(9), 1-58. Retrieved from https://drive.google.com/file/d/1yOnm_WSHp6rlmJgvoZycyjaPIPWykGKt/view

Sahamony, N. ., Meliyani, R., \& Idaman, S. (2021). Analisis Resiko Dampak Ekonomi Pada Saat Covid - 19. 15(6), 4649-4654.

Sholikhah, I., Purnomo, R., \& Abas, S. (2020). Industri Kreatif Pada Batik Tulis Tenun Gedog: Kondisi Sosial-ekonomi Pasca Covid-19. Jurnal Ekonomi, Manajemen Dan Akuntansi, 4(2), 198-211.

Sopanah, Syamsul Bahri, M. G. (2020). Strategi Pemberdayaan Masyarakat Melalui Ekonomi Kreatif Berbasis Kearifan Lokal. Conference on Innovation and Application of Science and Technology (CIASTECH 2020), (Ciastech), 61.

Yamali, F. R., \& Putri, R. N. (2020). Dampak Pandemi Covid-19 Terhadap Ekonomi Indonesia. Ekonomis: Journal of Economics and Business, 4(2), 384-388. https://doi.org/10.33087/ekonomis.v4i2.179 